\title{
Assemblages of carabid beetles (Col. Carabidae) and ground-dwelling spiders (Araneae) in natural and artificial regeneration of pine forests
}

\author{
A. Kosewska ${ }^{1,3}$, E. Topa $^{1}$, M. Nietupski ${ }^{1}$ and R. Kędzior ${ }^{2}$ \\ ${ }^{1}$ Department of Entomology, Phytopathology and Molecular Diagnostic, University of Warmia and Mazury in Olsztyn, \\ Prawochenskiego 17, 10-720 Olsztyn, Poland \\ ${ }^{2}$ Department of Ecology, Climatology and Air Protection, University of Agriculture in Krakow, Al. Mickiewicza 24/28, \\ 30-059 Krakow, Poland \\ ${ }^{3}$ Corresponding author:e-mail: a.kosewska@uwm.edu.pl
}

Keywords: Ground beetles, Ground-living spiders, Pine forest regeneration.

\begin{abstract}
Carabid beetles and spiders are at the top of the hierarchy of general invertebrate predators, which can help to reduce the abundance of harmful forest pests. They are also frequently used as environmental indicators. In this paper we analyzed the abundance, species richness and changes in carabid beetle and spider assemblages in three treatments of pine forest regeneration - natural, natural with soil prepared by ploughing and artificial with seedlings planted in ploughed soil. The most beneficial forest regeneration treatment variant of forest regeneration for carabid beetles and spiders was the natural regeneration of pine stands without any preceding soil preparation. Both taxa responded strongly to soil ploughing. We also noted the replacement of forest species by less sensitive open area species. In carabid assemblages, large changes in the trophic structure were observed, as predatory species were replaced by hemizoophages in the ploughed treatments.
\end{abstract}

Nomenclature: The World Spider Catalog (2017), Aleksandrowicz (2004).

Abbreviations: A - Artificial, Ab - Abundance, GLMM - General Linear Mixed effect Model, N - Natural, N+P - Natural with Ploughed soil, NMDS - Non-metric MultiDimensional Scaling, R - richness.

\section{Introduction}

Poland is a European leader in the total area of forests, which cover 9.2 million ha. In 2015, the forest coverage in Poland, calculated according to international standards, was 30.8\% (Forests in Poland 2016). The maintenance of such a high forest cover in our country and its predicted further growth depend on several factors, including the reproduction of stands. All afforestation efforts in Poland are based on the State Programme for Increasing Forest Coverage, which predicts that the total forest coverage in our country will rise to $33 \%$ by 2050 (Kaliszewski et al. 2014). Scots pine (Pinus silvestris L.) is the dominant species in forest tree stands, and the proportion of this species in the total forest cover in Poland is almost 60\% (Forests in Poland 2016). Sustainable forest management, the aim of which is to support and protect biodiversity by the use of natural regeneration methods and more mixed species stands, has become an overriding requirement in global forest policy (Kaliszewski et al. 2014). Most new forests in Polish silviculture are created artificially, mainly by planting. Self-planting pine trees as an alternative forest cultivation method should be promoted by making conscious efforts to create suitable conditions, including appropriate soil preparation, for the development of such new tree stands (Pigan 2010). Studies on various technologies applied to soil preparation under artificial and natural pine stands focus mostly on agrotech- nical and economic issues (Szramka 2005, Hallikainen et al. 2007, Aleksandrowicz-Trzcińska et al. 2014) rather than ecological. Natural regeneration of forests is more difficult than artificial renewal and bears a higher risk of cultured failure. However, it is an ecological approach to forest regeneration for which the potential benefits justify its use in Polish forests. The main advantage is that it contributes to a greater diversity of structures of pine stands, thus improving the processes that occur in forest ecosystems (Junker et al. 2000). Regeneration of forest communities via spontaneous succession is conducive of the development of more heterogeneous habitats, and therefore enhancing biodiversity (Kędzior et al. 2017, Sipos et al. 2017).

Predatory arthropods play many vital roles in forest ecosystems (Schuldt et al. 2008, Kotze et al. 2011) and their diversity is frequently used to assess the biological condition of habitats in applied forest research (Paillet et al. 2010, Taboada et al. 2010, Pedley and Dolman 2014). The ground beetles and ground-dwelling spiders, owing to their high sensitivity to changing environmental conditions, widespread occurrence and good availability for research, are among the most important bioindicators employed in environmental research (Rainio and Niemelä 2003, Pearce and Venier 2006, Maleque et al. 2009, Koivula 2011). Moreover, ground beetles and spiders are the taxa that are at the top of the hierarchy of general invertebrate predators which reduce the abundance of forest pests, which are 
responsible for economic losses. On the other hand, these taxa also indicate some natural and man-made disturbances, such as wildfires (Koponen 2005, Samu et al. 2010), forest harvesting (Junker et al. 2000, Huber et al. 2007) or pollution (Skalski et al. 2015, Tamutis and Skłodowski 2016). The conventional clear-cutting model with soil preparation as a treatment preceding the regeneration of a forest stand has a strong impact on assemblages of carabid beetles and spiders (Junker at al. 2000, Huber et al. 2007, Schwerk and Szyszko 2007, Skłodowski 2014). Thus far, choice of sustainable forest practice has been motivated by the need to preserve forest biodiversity, as this approach is less harmful to the environment, can protect assemblages of many groups of arthropods and complies with the Forest Policy (Schwerk and Szyszko 2011, Oxbrough et al. 2014, Nagy et al. 2016, Debnár et al. 2016).

The main objective of this study is to determine the species composition and diversity, as well as the abundance and structure of carabid and spider assemblages, in naturally and artificially regenerated pine stands. Another aim is to determine the responses of carabid beetles and spiders to disturbances caused by the establishment of regenerated pine forests. We predict that naturally regenerated forest stands without soil preparation treatments will be characterized by greater abundance and a higher number of species of ground-dwelling carabid beetles and spiders than naturally regrown forests on ploughed soil or artificially regenerated stands. Another purpose of our research is to verify whether soil ploughing under regenerated pine forests results in changes in the structure of the assemblages of carabids and spiders, with such manifestations as decreased abundance of forest predatory species and consequent increase in numbers of open habitat species.

\section{Materials and methods}

\section{Data collection}

The experiment was conducted in northeastern Poland (Fig. 1a). The research sites represented three treatments:

$\mathrm{N}$ - naturally regenerated pine stand - plots without previous soil preparation,

$\mathrm{N}+\mathrm{P}$ - regeneration of natural pine forest with traditional soil preparation (ploughing with a double moldboard forest plough),

A - artificial regeneration of pine stand (by planting) with traditional soil preparation (ploughing with a double moldboard forest plough).

Four research sites in each treatment (12 sites in total) were selected in two Forest Districts (Kudypy and Olsztynek), situated about $50 \mathrm{~km}$ away from each other (Fig. 1b). The research sites were selected so as to ensure that the parameters which characterised them were as similar as possible, and therefore the sites could be treated as replications of the analysed pine regeneration treatments. In both forest districts, before tree felling, the research sites had a fresh mixed coniferous forest with a distinct prevalence of pine (at least $80 \%$ ) in the tree stand, growing on moderately wet brown podzolic soils. Also matrix around the sites was similar, with mixed coniferous forest with predominance of pine trees in age between 40 and 100. On the studied sites the trees were felled in 2014, and the pine trees' cutting age was 101-126 years. In 2015 , on previously prepared soil for artificial regeneration (A) and natural regeneration on ploughed soil $(\mathrm{N}+\mathrm{P})$, the soil was ploughed with a double moldboard forest plough. In the spring of 2016, the artificial regeneration site was planted with pine seedlings, while the remaining area was left for a)

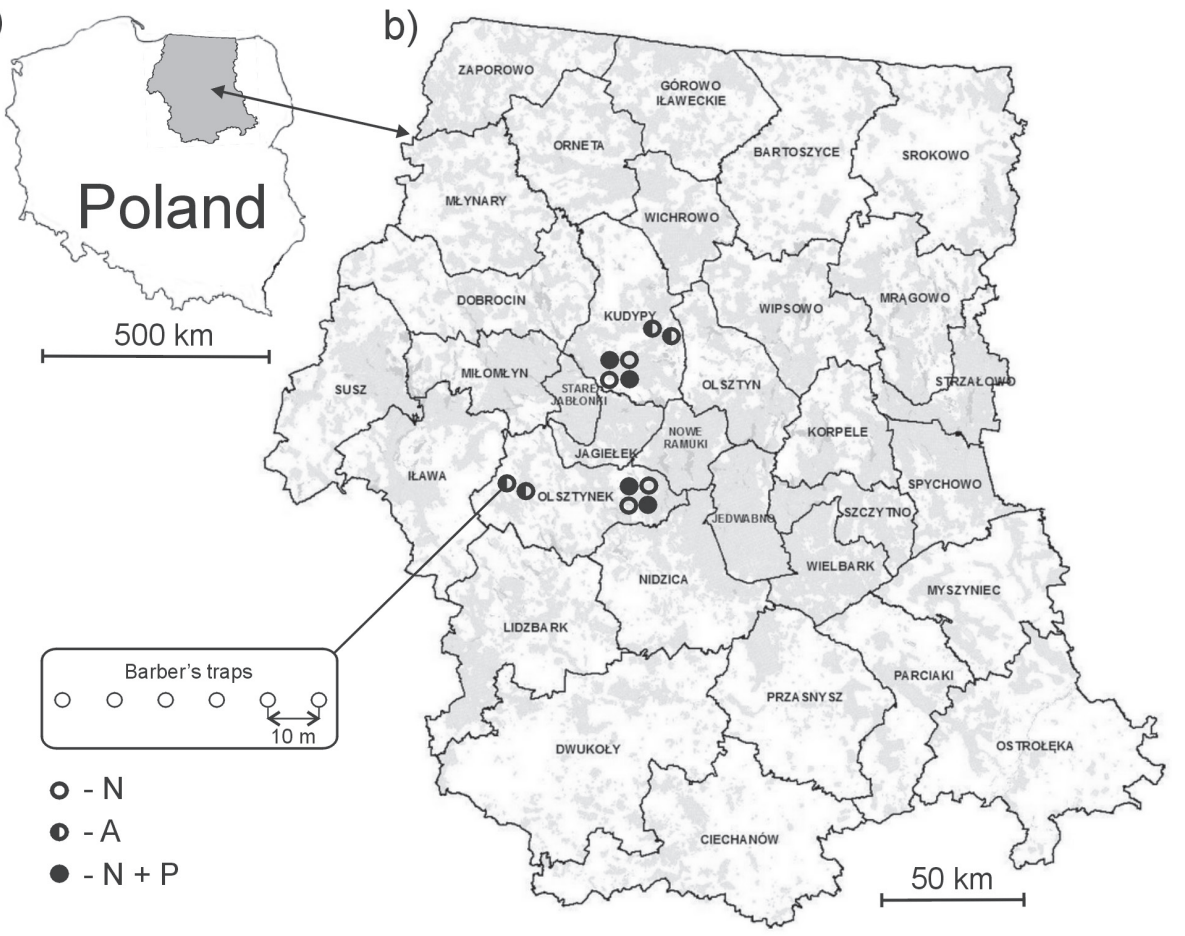

Figure 1. The location of the study area, with the distribution of sampling sites and traps; a: a contour map of Poland, in which the grey shaded area is administered by the Regional Directorate of State Forests in Olsztyn, b: division into forest districts in the Regional Directorate of State Forests in Olsztyn, with the marked District Kudypy and District Olsztyn, where the study was conducted. 
Table 1. Description and characteristics of the studied sites.

\begin{tabular}{|c|c|c|c|c|c|c|c|}
\hline \multirow{2}{*}{$\begin{array}{r}\text { Study } \\
\text { area }\end{array}$} & \multirow{2}{*}{ District } & \multicolumn{2}{|c|}{ Coordinates } & \multirow{2}{*}{$\begin{array}{l}\text { Height above } \\
\text { see level (m) }\end{array}$} & \multirow{2}{*}{$\begin{array}{l}\text { Type } \\
\text { of soil }\end{array}$} & \multicolumn{2}{|c|}{ Stand before cutting } \\
\hline & & $\mathrm{N}$ & E & & & Species & Cutting age \\
\hline N 1 & Kudypy & $53^{\circ} 46^{\prime} 29^{\prime \prime}$ & $20^{\circ} 14^{\prime} 38^{\prime \prime}$ & 138 & \multirow{15}{*}{ 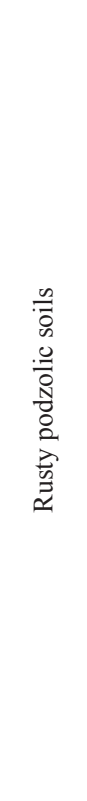 } & pine $80 \%$ & 126 \\
\hline \multirow[t]{2}{*}{$\mathrm{N} 2$} & Kudypy & $53^{\circ} 46^{\prime} 38^{\prime}$ & $20^{\circ} 14^{\prime} 24^{\prime \prime}$ & 140 & & birch $10 \%$ & 61 \\
\hline & & & & & & spruce $10 \%$ & 61 \\
\hline N 3 & Olsztynek & $53^{\circ} 31^{\prime} 47^{\prime \prime}$ & $20^{\circ} 25^{\prime} 16^{\prime \prime}$ & 156 & & \multirow{2}{*}{ pine $100 \%$} & \multirow{2}{*}{101} \\
\hline $\mathrm{N} 4$ & Olsztynek & $53^{\circ} 31^{\prime} 45^{\prime \prime}$ & $20^{\circ} 25^{\prime} 10^{\prime \prime}$ & 156 & & & \\
\hline $\mathrm{N}+\mathrm{P} 1$ & Kudypy & $53^{\circ} 46^{\prime} 35^{\prime \prime}$ & $20^{\circ} 14^{\prime} 44^{\prime \prime}$ & 136 & & pine $80 \%$ & 126 \\
\hline \multirow[t]{2}{*}{$\mathrm{N}+\mathrm{P} 2$} & \multirow[t]{2}{*}{ Kudypy } & \multirow[t]{2}{*}{$53^{\circ} 46^{\prime} 33^{\prime \prime}$} & \multirow[t]{2}{*}{$20^{\circ} 14^{\prime} 24^{\prime \prime}$} & \multirow[t]{2}{*}{140} & & birch $10 \%$ & 61 \\
\hline & & & & & & spruce $10 \%$ & 61 \\
\hline $\mathrm{N}+\mathrm{P} 3$ & Olsztynek & $53^{\circ} 31^{\prime} 44^{\prime \prime}$ & $20^{\circ} 25^{\prime} 17^{\prime \prime}$ & 156 & & & \\
\hline $\mathrm{N}+\mathrm{P} 4$ & Olsztynek & $53^{\circ} 31^{\prime} 47^{\prime \prime}$ & $20^{\circ} 25^{\prime} 09^{\prime \prime}$ & 156 & & Pाit sovo & Not \\
\hline A 1 & Kudypy & $53^{\circ} 46^{\prime} 03^{\prime \prime}$ & $20^{\circ} 16^{\prime} 42^{\prime \prime}$ & 143 & & pine $80 \%$ & 120 \\
\hline \multirow[t]{2}{*}{ A 2} & \multirow[t]{2}{*}{ Kudypy } & \multirow[t]{2}{*}{$53^{\circ} 46^{\prime} 07^{\prime \prime}$} & \multirow[t]{2}{*}{$20^{\circ} 16^{\prime} 36^{\prime \prime}$} & \multirow[t]{2}{*}{143} & & birch $10 \%$ & 90 \\
\hline & & & & & & spruce $10 \%$ & 70 \\
\hline A 3 & Olsztynek & $53^{\circ} 32^{\prime} 11^{\prime \prime}$ & $20^{\circ} 16^{\prime} 58^{\prime \prime}$ & 172 & & 0 & 10 \\
\hline A 4 & Olsztynek & $53^{\circ} 32^{\prime} 18^{\prime \prime}$ & $20^{\circ} 16^{\prime} 47^{\prime \prime}$ & 172 & & pilic sovo & 101 \\
\hline
\end{tabular}

self-planting from the so-called biogroups, i.e. fragments of tree stands comprising approximately $5 \%$ of the trees remaining on the cleared forest sites. An algorithm used to select areas for common pine afforestation was based on economic data contained in the forest management plan comprising: composition of tree stands (pine trees) and a habitat which raises the hope that natural afforestation will succeed (fresh mixed coniferous forest exposed to small competition by the substratum plants). More details on each of the research locations are provided in Table 1.

In both Forest Districts, two sites, at least $200 \mathrm{~m}$ from each other, were selected for each combination (Fig. 1b). On each research site, six Barber traps were installed to catch epigeic entomofauna. Traps were set every 10 meters along transects running through the center of each research site. Insects were trapped from the second half of April to mid-October 2016. The traps were emptied every two to three weeks and whole time series of a trap was treated as one sampling unit. The trap is the elementary sampling unit.

\section{Data analysis}

The collected material was identified to species. Spiders were identified using a key (Netwig et al. 2017) and following the nomenclature of the World Spider Catalog (2017). Habitat affinity characteristic (forest spiders, generalist spiders, open area spiders) were derived from Hänggi et al. 1995. For the Carabidae, the key of Hůrka (1996) and nomenclature proposed by Aleksandrowicz (2004) were used. Carabid beetles were analysed in terms of their species composition, abundance, richness and some life history traits. Life history traits used in the analysis were food preferences (hemizoophages, and predators: large $>15 \mathrm{~mm}$, medium $15-5 \mathrm{~mm}$, small $<5$ $\mathrm{mm}$ ) and habitat specialization (forest species, generalists, open area species). In order to specify ecological characteristics of the Carabidae, we referred to the following papers: Sharova (1974); Lindroth (1985, 1986); Aleksandrowicz (2004). The Shannon species diversity index (H', natural logarithm) was used to identify the diversity of carabid and spider assemblages. Differences between mean values of abundance, number of species, and diversity index, as well as the total abundance of invertebrates representing particular life traits between the study sites, were tested using general linear mixed effect model (GLMM), in which location was a random factor, and the fixed effects included treatment (treatment nested in location). The differences between the types of regeneration methods were compared using the Bonferroni post-hoc test. The analyses were performed using STATISTICA for Windows v. 12. Indirect ordination of carabid beetle and spider assemblages was performed using non-metric multidimensional scaling (NMDS). NMDS was calculated in PAST software (Hammer et al. 2001) on a BrayCurtis similarity matrix. The distance between assemblages was analyzed by ANOSIM (Anderson 2001) using the PAST software. Similarity percentage analyses SIMPER (also calculated using PAST software) (Clarke 1993) were used to determine the relative contribution of various species to the pine stand regeneration treatments.

\section{Results}

In total, 5194 individuals representing 70 species of carabid beetles and 3459 spiders representing 83 species were collected. The sampled material was analyzed for the three 
Table 2. Number of individuals and species of Carabidae and Araneae and diversity in three pine regeneration treatments $(\mathrm{N}-$ natural, $\mathrm{N}+\mathrm{P}-$ natural with ploughed soil, $\mathrm{A}-$ artificial).

\begin{tabular}{ccccccc}
\hline \multirow{2}{*}{ Combination } & \multicolumn{2}{c}{ Number of Individuals } & \multicolumn{2}{c}{ Number of species } & \multicolumn{2}{c}{ Shannon H' diversity } \\
\cline { 2 - 7 } & Carabidae & Araneae & Carabidae & Araneae & Carabidae & Araneae \\
\hline $\mathrm{N}$ & 2181 & 2067 & 49 & 76 & 2.413 & 3.169 \\
$\mathrm{~N}+\mathrm{P}$ & 1163 & 603 & 47 & 44 & 2.632 & 2.645 \\
$\mathrm{~A}$ & 1850 & 789 & 57 & 45 & 2.503 & 2.531 \\
Total & 5194 & 3459 & 70 & 83 & & \\
\hline \hline
\end{tabular}

Table 3. Analysis with a linear mixed effect model for abundance, richness and Shannon diversity of carabid beetles and spiders.

\begin{tabular}{lccc}
\hline Carabidae & & & \\
\hline Individuals & $\mathrm{df}$ & $\mathrm{F}$ & $\mathrm{p}$ \\
\hline Intercept & 1 & 424.55 & 0.000 \\
Treatment & 2 & 12.73 & 0.000 \\
Location (Treatment) & 3 & 0.55 & 0.651 \\
\hline Species & $\mathrm{df}$ & $\mathrm{F}$ & $\mathrm{p}$ \\
\hline Intercept & 1 & 1583.56 & 0.000 \\
Treatment & 2 & 4.81 & 0.011 \\
Location (Treatment) & 3 & 1.58 & 0.202 \\
\hline Shannon H' & $\mathrm{df}$ & $\mathrm{F}$ & $\mathrm{p}$ \\
\hline Intercept & 1 & 4926.87 & 0.000 \\
Treatment & 2 & 2.44 & 0.095 \\
Location (Treatment) & 3 & 6.617 & 0.001 \\
\hline Araneae & & & \\
\hline Individuals & $\mathrm{df}$ & $\mathrm{F}$ & $\mathrm{p}$ \\
\hline Intercept & 1 & 332.26 & 0.000 \\
Treatment & 2 & 53.10 & 0.000 \\
Location (Treatment) & 3 & 6.67 & 0.001 \\
\hline Species & $\mathrm{df}$ & $\mathrm{F}$ & $\mathrm{p}$ \\
\hline Intercept & 1 & 1181.83 & 0.000 \\
Treatment & 2 & 94.77 & 0.000 \\
\hline Location (Treatment) & 3 & 8.89 & 0.000 \\
\hline Shannon H' & $\mathrm{df}$ & $\mathrm{F}$ & $\mathrm{p}$ \\
\hline \hline Treatment & 3 & 31.27 & 0.000 \\
\hline
\end{tabular}

pine regeneration treatments (Table 2). Both groups of invertebrates were most numerous in naturally regenerated pine stands. The most abundant carabid beetle species were Harpalus rufipes (17\%), Harpalus rufipalpis (16\%), Amara lunicollis (15\%), Carabus arvensis (9\%) and Pterostichus oblongopunctatus (8\%). The most abundant spider species were from the Lycosidae family and included Pardosa lugubris (18\%), Pardosa pullata (10\%), Trochosa terricola (9\%) and Pardosa riparia (8\%).

The naturally regenerated pine forest without ploughing was distinguished by a particularly high Shannon diversity for spider species (Table 2). The GLMM revealed that differences in assemblage characteristics were influenced by location, even though the research sites had been selected on the basis of their parametric similarity. The post-hoc Bonferroni test showed that the number of individuals, species richness, and Shannon diversity of spiders were significantly higher in naturally regenerated forests $(\mathrm{N})$ than in the other treatment (Fig. 2). Statistically significant differences were also recorded between the types of regenerated forest with respect to average numbers of carabid beetle individuals and species caught, although here the location of the study sites was not a significant factor (Table 3). The highest average number of carabid beetles was recorded in the natural regeneration treatment without soil preparation (Fig. 3) The lowest number of beetles was recorded on sites with the treatment regeneration with natural pine on ploughed soil. The average number of carabid species in artificially regenerated forest was the highest and statistically different than in the natural regeneration treatment with soil preparation (Fig. 3). In the case of the mean diversity index, treatment was not a significant factor, unlike location (Table 3, Fig. 3).

The NMDS analysis demonstrated high variation of the analyzed assemblages of carabids and spiders (Fig. 4). In the case of carabid beetles, their assemblages from natural $(\mathrm{N})$ and artificial (A) treatments were totally different. The diagram shows a high degree of order within the carabid beetle assemblages in the natural sites without soil preparation and in the artificial pine wood (Fig. 4 - left). The natural restoration of a forest on ploughed soil treatment $(\mathrm{N}+\mathrm{P})$ is characterized by great disorder and haphazard distribution of species. It encompasses large parts of forests regenerated without human intervention, as well as artificially created woods. Regarding the spiders, all variants of the experiment had a shared set of species, but they also showed considerable dissimilarity (Fig. 4 - right). The most different assemblages of spiders were found in the natural pine regeneration site $(\mathrm{N})$.

The composition of the most numerous species of carabids and spiders in the regenerated forests was similar. The SIMPER analysis shows which of the species had the strongest effect on the differences between the examined assemblages. With respect to carabid beetles, when the natu- 
rally restored forest without ploughing treatment $(\mathrm{N})$ was compared with the naturally regrown forest with previously ploughed soil treatment $(\mathrm{N}+\mathrm{P})$, the degree of dissimilarity reached $67.48 \%$ (Appendix, Table A1). The largest contribution to this discrepancy was made by the species A. lunicollis, C. arvensis, H. rufipalpis, P. oblongopunctatus, H. rufipes and Pterostichus niger. The dissimilarity percentage between the naturally regenerated site without ploughing $(\mathrm{N})$ and artificially restored forest site (A) equalled 67.02, and the species which contributed the most to this discrepancy were $A$.
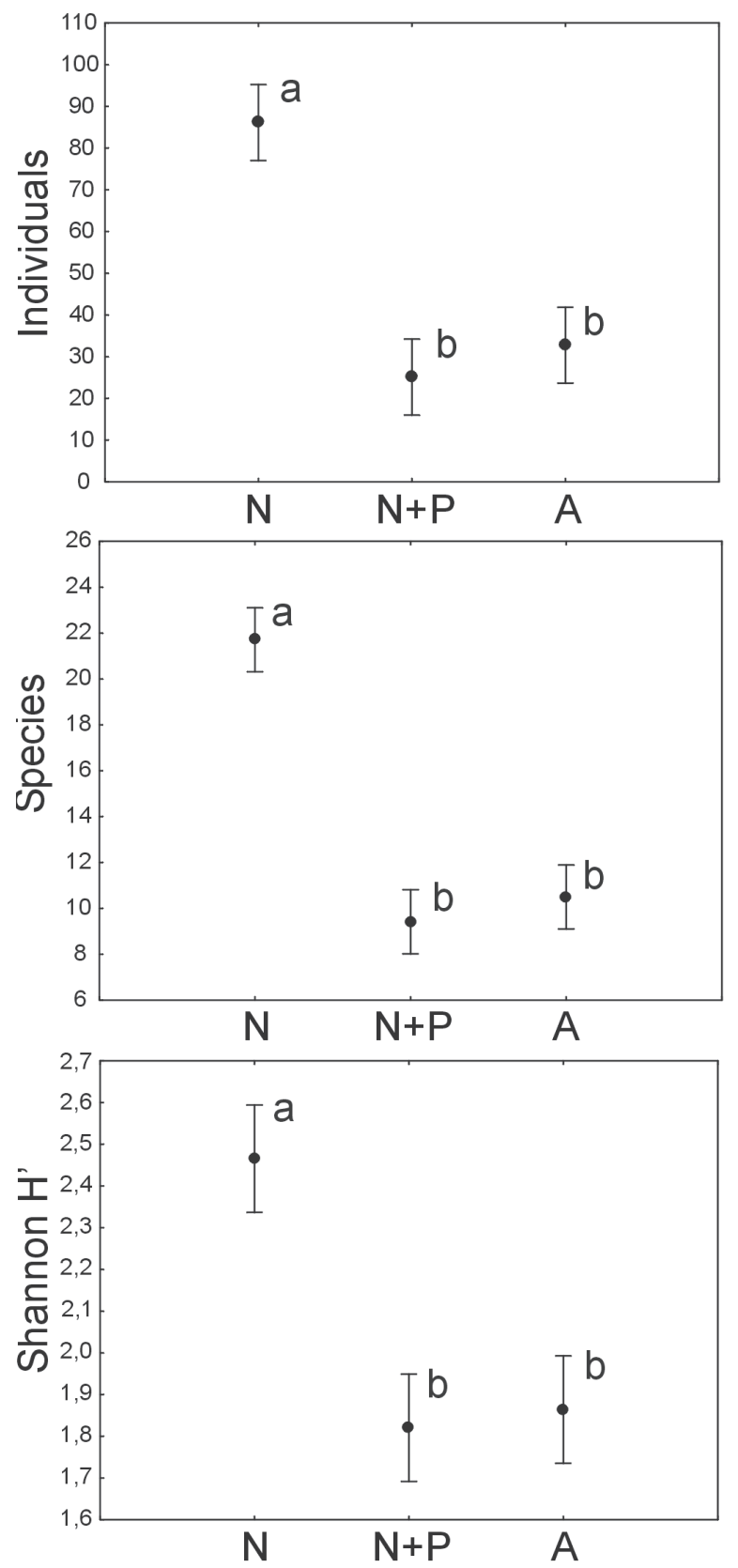

Figure 2. Mean abundance, species richness and Shannon diversity of the spiders in the three treatments. Vertical lines denote SE; $a, b . .$. - means indicated by the same letter do not differ according to the Bonferroni test. lunicollis, which most strongly avoided artificial forest sites, and $H$. rufipes, which was much more numerous in the artificial than the natural sites. This species, together with $H$. rufipalpis, preferred habitats with artificially planted pine trees and had the main influence on the pattern of differences between the habitats with artificially regenerated forest (A) and with naturally grown forest on ploughed soil $(\mathrm{N}+\mathrm{P})$, where the general dissimilarity index was $63.04 \%$. With respect to spiders, species of the family Lycosidae comprised most of the assemblages and had an effect on the differences between
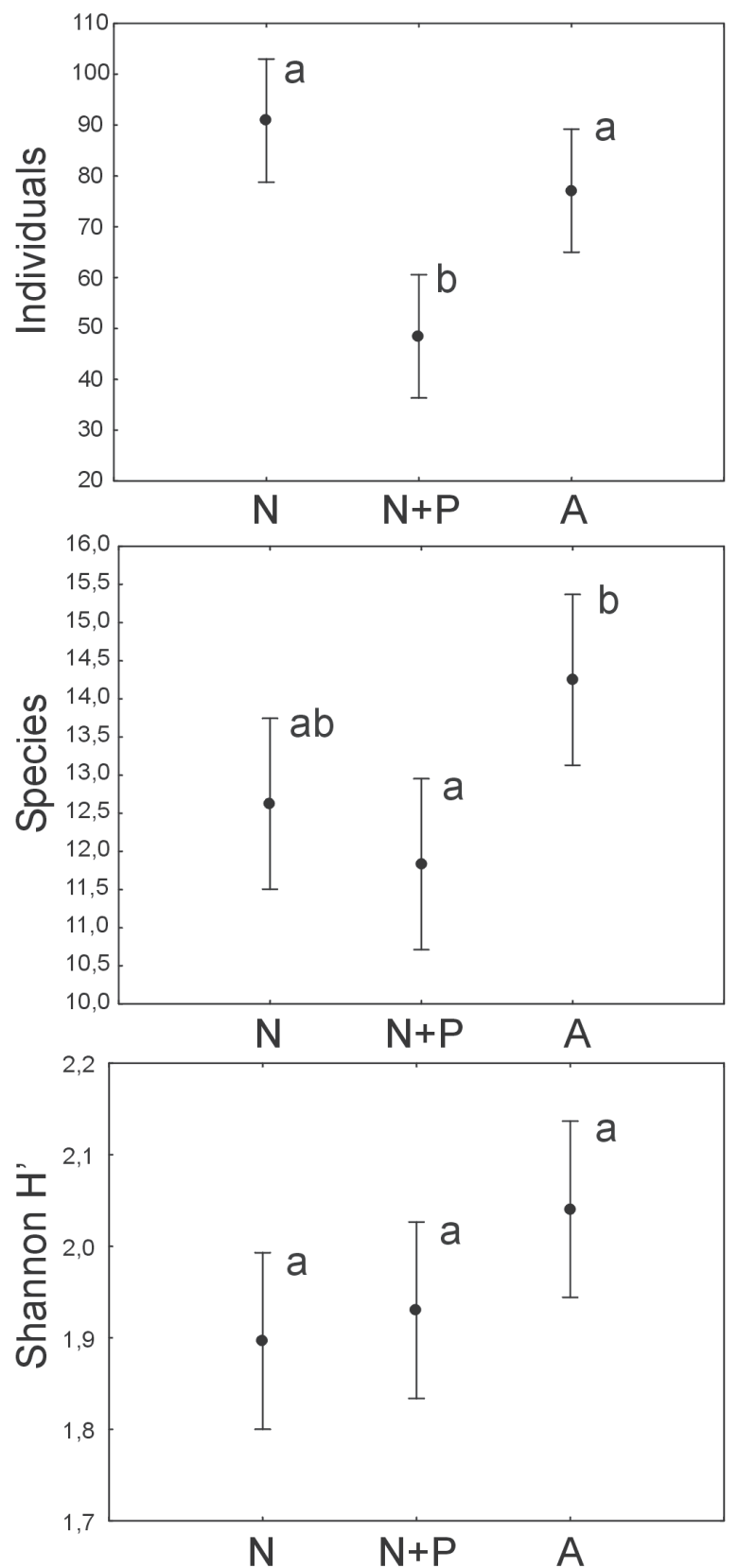

Figure 3. Mean abundance, species richness and Shannon diversity of the carabids in the three treatments. Vertical lines denote SE; $a, b . .$. - means indicated by the same letter do not differ according to the Bonferroni test. 
Table 4. Ecological description of the carabid beetles and spiders recorded in the pine regeneration treatments.

\begin{tabular}{|c|c|c|c|c|c|c|}
\hline \multirow{3}{*}{ Ecological description } & \multicolumn{6}{|c|}{ Pine regeneration } \\
\hline & \multicolumn{2}{|c|}{$\mathrm{N}$} & \multicolumn{2}{|c|}{$\mathrm{N}+\mathrm{P}$} & \multicolumn{2}{|c|}{ A } \\
\hline & $\mathrm{R}[\%]$ & $\mathrm{Ab}[\%]$ & $\mathrm{R}[\%]$ & $\mathrm{Ab}[\%]$ & $\mathrm{R}[\%]$ & $\mathrm{Ab}[\%]$ \\
\hline \multicolumn{7}{|c|}{ Carabidae } \\
\hline \multicolumn{7}{|l|}{ Trophic structure } \\
\hline Large predators & 18.37 & 25.08 & 17.02 & 10.83 & 19.30 & 18.00 \\
\hline Medium predators & 26.53 & 22.01 & 27.66 & 30.78 & 28.07 & 26.32 \\
\hline Small predators & 12.24 & 1.19 & 14.89 & 2.58 & 15.79 & 1.89 \\
\hline Hemizoophages & 42.86 & 51.72 & 40.43 & 55.80 & 36.84 & 53.78 \\
\hline \multicolumn{7}{|l|}{ Habitat preferences } \\
\hline Forest species & 34.69 & 39.02 & 29.79 & 28.80 & 28.07 & 19.84 \\
\hline Open area species & 55.10 & 60.06 & 57.45 & 69.39 & 59.65 & 73.14 \\
\hline Generalistc species & 10.20 & 0.92 & 12.77 & 1.81 & 12.28 & 7.03 \\
\hline \multicolumn{7}{|c|}{ Araneae } \\
\hline Forest spiders & 32.89 & 41.03 & 25.00 & 59.20 & 28.89 & 31.18 \\
\hline Generalist spiders & 14.47 & 10.89 & 13.64 & 11.44 & 8.89 & 14.20 \\
\hline Open area spiders & 52.63 & 48.09 & 61.36 & 29.35 & 62.22 & 54.25 \\
\hline
\end{tabular}

R - Richness; Ab - Abundance
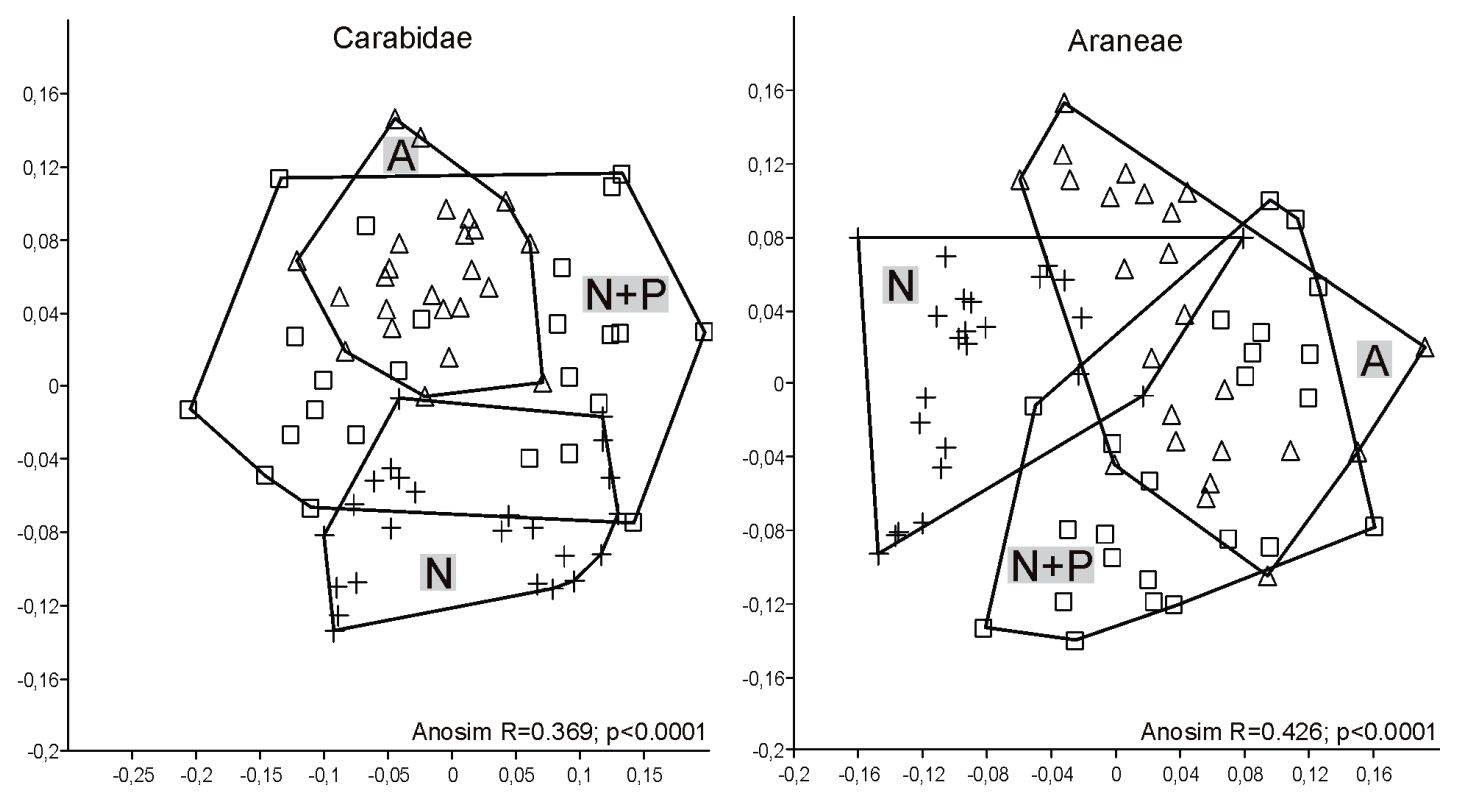

Figure 4. Diagram of non-metric multidimensional scaling (NMDS) for carabids (left) and spiders (right) in relation to treatment.

the groups (Appendix, Table A2). The dissimilarity between the naturally regenerated forest without ploughing $(\mathrm{N})$ and naturally regenerated forest on ploughed soil $(\mathrm{N}+\mathrm{P})$ was $77.39 \%$. The greatest influence on the differences between the taxa was demonstrated by P. lugubris, Pardosa palustris and $P$. riparia. The percentage of dissimilarity between the naturally $(\mathrm{N})$ and artificially $(\mathrm{A})$ regenerated forests was
77.25, and was mostly contributed by P. lugubris and P. pullata. These species also contributed the most to the differences between assemblages of arachnids caught in the naturally regenerated forest on ploughed soil $(\mathrm{N}+\mathrm{P})$ and artificially regenerated forest (A).

Carabid beetles and spiders are known to be good bioindicators because of their sensitivity to environmental chang- 
Table 5. Analysis with a linear mixed effect model for life traits of carabid beetles and spiders.

\begin{tabular}{|c|c|c|c|}
\hline \multicolumn{4}{|c|}{ Carabidae } \\
\hline Large predators & df & $\mathrm{F}$ & $\mathrm{p}$ \\
\hline Intercept & 1 & 165.93 & 0.000 \\
\hline Treatment & 2 & 21.80 & 0.000 \\
\hline Location (Treatment) & 3 & 19.68 & 0.000 \\
\hline Medium predators & df & $\mathrm{F}$ & $\mathrm{p}$ \\
\hline Intercept & 1 & 301.89 & 0.000 \\
\hline Treatment & 2 & 2.71 & 0.074 \\
\hline Location (Treatment) & 3 & 6.74 & 0.001 \\
\hline Small predators & df & $\mathrm{F}$ & $\mathrm{p}$ \\
\hline Intercept & 1 & 42.55 & 0.000 \\
\hline Treatment & 2 & 0.31 & 0.73 \\
\hline Location (Treatment) & 3 & 7.14 & 0.000 \\
\hline Hemizoophages & df & $\mathrm{F}$ & $\mathrm{p}$ \\
\hline Intercept & 1 & 218.81 & 0.000 \\
\hline Treatment & 2 & 5.22 & 0.007 \\
\hline Location (Treatment) & 3 & 10.33 & 0.000 \\
\hline Forest species & df & $\mathrm{F}$ & $\mathrm{p}$ \\
\hline Intercept & 1 & 315.21 & 0.000 \\
\hline Treatment & 2 & 32.77 & 0.000 \\
\hline Location (Treatment) & 3 & 20.49 & 0.000 \\
\hline Open area species & $\mathrm{df}$ & $\mathrm{F}$ & $\mathrm{p}$ \\
\hline Intercept & 1 & 271.39 & 0.000 \\
\hline Treatment & 2 & 6.23 & 0.003 \\
\hline Location (Treatment) & 3 & 6.40 & 0.001 \\
\hline Generalists & $\mathrm{df}$ & $\mathrm{F}$ & $\mathrm{p}$ \\
\hline Intercept & 1 & 76.27 & 0.000 \\
\hline Treatment & 2 & 31.28 & 0.000 \\
\hline Location (Treatment) & 3 & 29.82 & 0.000 \\
\hline \multicolumn{4}{|c|}{ Araneae } \\
\hline Forest spiders & df & $\mathrm{F}$ & $\mathrm{p}$ \\
\hline Intercept & 1 & 82.40 & 0.000 \\
\hline Treatment & 2 & 12.05 & 0.000 \\
\hline Location (Treatment) & 3 & 5.69 & 0.002 \\
\hline Open area spiders & df & $\mathrm{F}$ & $\mathrm{p}$ \\
\hline Intercept & 1 & 213.16 & 0.000 \\
\hline Treatment & 2 & 43.80 & 0.000 \\
\hline Location (Treatment) & 3 & 9.45 & 0.000 \\
\hline Generalists spiders & $\mathrm{df}$ & $\mathrm{F}$ & $\mathrm{p}$ \\
\hline Intercept & 1 & 156.74 & 0.000 \\
\hline Treatment & 2 & 18.52 & 0.000 \\
\hline Location (Treatment) & 3 & 2.46 & 0.071 \\
\hline
\end{tabular}
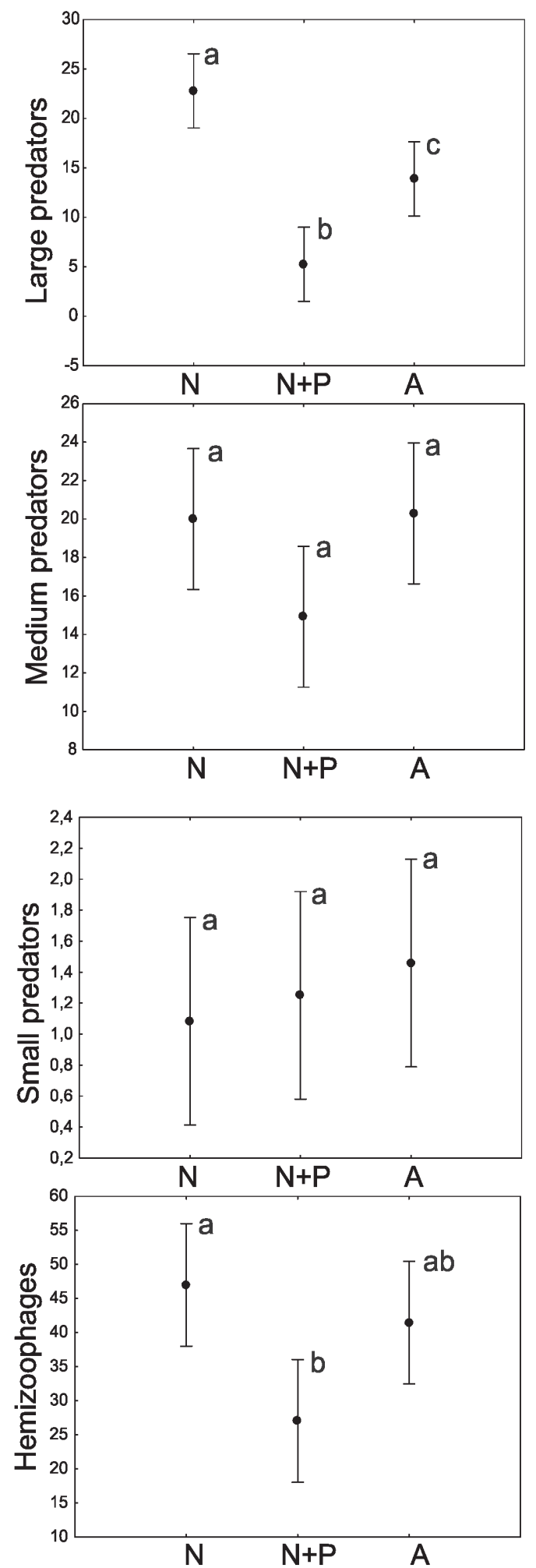

Figure 5. Mean abundance of carabids with different food preferences in three treatments. Vertical lines denote SE; a, b, c means indicated by the same letter do not differ according to the Bonferroni test. 

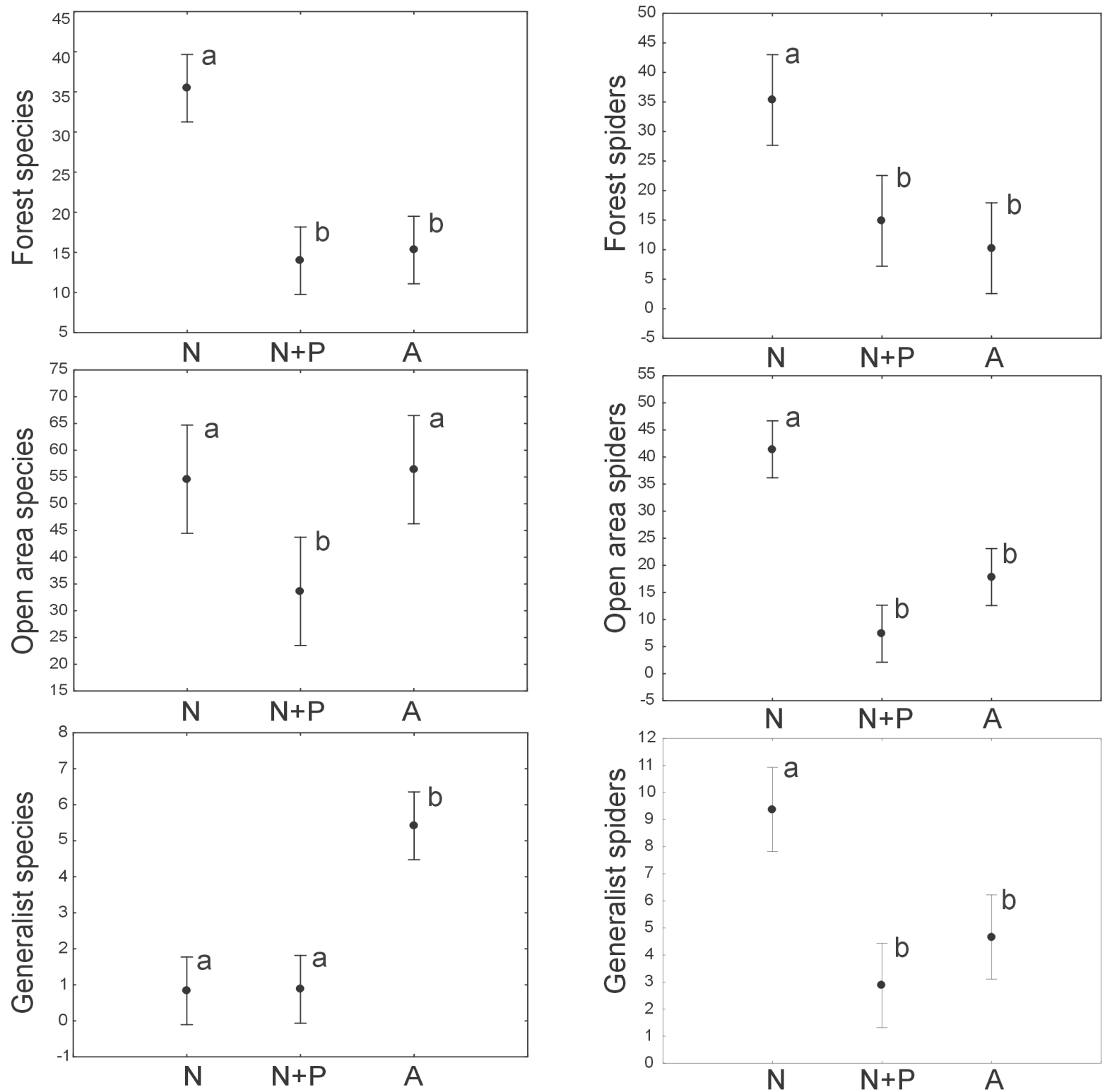

Figure 6. Mean abundance of carabids with different habitat preferences according to treatment. Vertical lines denote SE; a, b... - means indicated by the same letter do not differ using the Bonferroni test.

es and certain life history traits, which were also analysed (Table 4). Considerable differences in the mean abundance of various ecological groups of carabid beetles and spiders were recorded according to treatment and location (Table 5). Feeding preferences are an important factor in the structure of carabid assemblages. Hemizoophages were the most numerous group of carabids, with respect to the number of both species and individuals recorded (Table 4). They preferred naturally regenerated forests without soil preparation (Fig. 5). Large predators responded even more strongly to both treatment and location than the hemizoophages did (Table 5). They appeared in substantially higher numbers in the naturally regenerated forest on unprepared soil than in the other two types of regenerated stands. When a forest regrew on

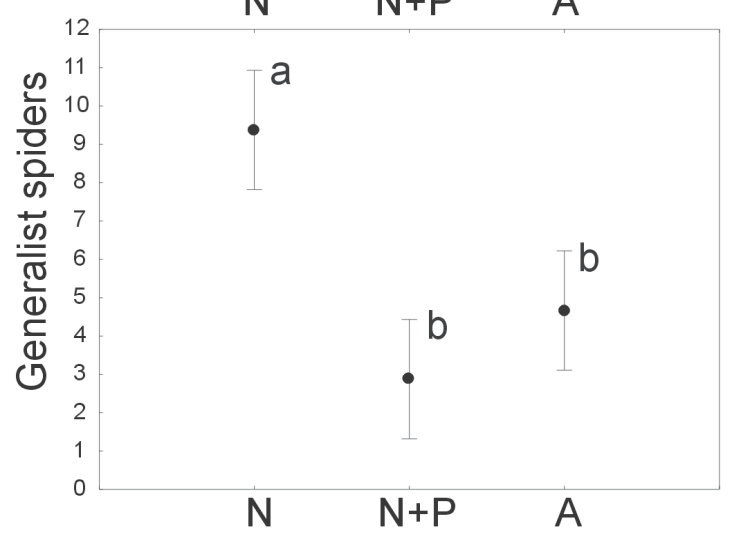

Figure 7. Mean abundance of spiders with different habitat preferences according to treatment. Vertical lines denote SE; a, b... - means indicated by the same letter do not differ using the Bonferroni test.

ploughed soil, the number of hemizoophages decreased considerably. However, there were no significant differences in the abundance of medium and small predatory carabid beetles between the three treatments (Fig. 5). Regarding habitat requirements, statistically significant differences were recorded according to treatment (Table 5). The most numerous group comprised open habitat beetles, which were constituted more than half of the assemblages in all three treatments (Table 4). A statistically significantly lower number of open habitat carabid beetles was recorded in the naturally regrown forest on ploughed soil $(\mathrm{N}+\mathrm{P})$ compared to the other two treatments (Fig. 6). Forest ground beetles, which constituted about 30\% in all carabid assemblages, evidently preferred natural forests $(\mathrm{N})$ without any ploughing - their number in such forests 
was much higher than in the other two treatments. Generalist species tended to choose artificially regenerated forest stands (A), where their number was statistically higher than in naturally regenerated forests. Spiders were also analyzed in terms of their habitat preferences. With respect to the number of spiders captured in each treatment, the most numerous were open habitat species (Table 4). Concerning the number of species, this group was also very large, especially in artificially regenerated forest stands. The second most numerous group comprised forest spiders. In the naturally regenerated forest on ploughed soil, their proportion exceeded 59\%. In natural forests, with no human intervention, this group comprised $33 \%$ and $41 \%$ with respect to the number of species and the number of individuals, respectively. Differences in the mean numbers of caught Araneae individuals between the treatments and depending on their habitat preferences, were significant (Table 5). In respect of the forest species, they appeared significantly more numerously in the naturally regenerated forest on unploughed soil $(\mathrm{N})$. The other two treatments did not differ significantly from each other (Fig. 7). A similar relationship was observed in the case of generalists. Open habitat spiders were also most numerous in the naturally regenerated forest, being significantly less numerous in both ploughed treatments.

\section{Discussion}

Proper management of forests is an issue that foresters and forest researchers have been considering for decades. The appropriate management of forest resources is linked to many aspects, e.g. practical, economic or, seen very broadly, environmental issues. The latter comprise questions related to biodiversity. Natural regeneration of tree stands is an approach that can contribute to the enhancement of biodiversity (Matuszkiewicz et al. 2013), although the Report of the State of Europe's Forests (2015) suggests that natural regeneration is not always a suitable method leading to the attainment of the conservation goal. One of the techniques to trace sustainability in forest management is the monitoring of indicator species (Pearce and Venier 2006, Jelaska et al. 2011). In our studies conducted on invertebrates from the Carabidae and Araneae taxa in naturally and artificially regenerated pine forests, high numbers of individuals and a rich species diversity were recorded. Some authors (Niemelä et al. 1993, Magura et al. 2015) report that carabid beetles in particular respond to any disturbances, e.g. felling of trees, by increasing their species richness. The pine regeneration treatments were established on cleared forest sites, which may have induced the observed response of the analyzed invertebrates, which were colonizing a new territory, thus taking advantage of new sources of food. Oxbrough et al. (2006), in a study on spiders, pointed to fragments of open space in forests as contributors to the species richness of forests. Both carabid beetles and spiders yielded much higher numbers of individuals in natural stands, without human intrusion into soil preparation. Despite the significantly lower abundance in regenerated forests on ploughed soil, carabids did not respond to this factor as strongly as spiders. Similar observations have been report- ed by Oxbrough et al. (2005) and Pedley and Dolman (2014). Regarding Araneae, their abundance and number of species decreased dramatically in pine sites regenerated on ploughed soil, whether it had been prepared for naturally or artificially planted pine trees. Natural regeneration of pine forests was distinguished by a very high (compared to the other types of tree renewal) value of the Shannon index of diversity $\left(\mathrm{H}^{\prime}=\right.$ 3.169). However, this index demonstrated significant differences in the pine stands regenerated in different ways only for spiders. The diversity of carabid beetles was affected by location rather than treatment. It is difficult to determine the underlying reasons, because the sites selected for the research were very similar to one another in the habitat, composition of tree stands, soil conditions or moisture, as well as bearing some semblance in the forest management both before and after tree felling, or the neighbouring areas, which consisted of fresh coniferous forest with the prevalence of pine. Most probably, the microclimate characteristic for each site, or some other factors which we did not examine, contributed to the fact that the location in some cases was more significant than the distinctly seen treatment. However, in the vast majority of the analyses, it was the treatment effect that proved to be more significant statistically in terms of individuals and species of carabid beetles than the location.

Some researchers claim that overall diversity is not a good indicator to describe the effect of silvicultural processes on assemblages of invertebrates, indicating the role of functional traits of these animals (Pohrl et al. 2007, Magura et al. 2015, Nagy et al. 2016). Also in our study, a negative effect of soil ploughing on life history traits was observed. Many studies suggest that this factor as a substantial one in changes within the structure of assemblages of invertebrates (Kromp 1999, Holland and Luff 2000, Skłodowski 2010, 2014, 2016, Kosewska et al. 2014). Nagy et al. (2015) in their studies of Staphylinidae, recommended that mechanical soil preparation before reforestation should be omitted during forest management. They claim that mechanical soil preparation eliminates the original microsites and alters microclimatic conditions, which cause the disappearance of sensitive specialist species. Also Tamutis and Skłodowski (2016) concluded that the establishment of cleared forest and ploughing had a negative influence on forest rove beetle species. A similar relationship was observed in the case of carabid beetles and spiders. The proportion of the forest fauna is largely reduced to the advantage of open habitat species among both Carabidae and Araneae. Pearce and Venier (2006), as well as Nagy et al. (2016), attribute this development to several factors, including the elimination micro-environments that are essential for the forest fauna, which leads to their gradual disappearance and replacement by more adaptable species. In our study, the most flexible species of carabid beetles, not responding significantly to ploughing, were the ones which belonged to medium and small zoophages. As a rule, species which belong to these ecological groups are indicated as the first to colonize new areas (Purvis and Fadl 2002) which was also noted in the pine regeneration sites we studied.

In order to determine the differences in the composition of carabid beetles and spiders, we used the SIMPER analysis, 
which is based on the degree of dissimilarity between assemblages, and which can show which species have the greatest influence on the differences. The SIMPER analysis enabled us to identify the species which were the main dominant species in each treatment. Among the forest carabid beetles, the species $C$. arvensis demonstrably avoided ploughed soil surfaces. Similarly, P. niger and P. oblongopunctatus were more numerous in tree stands with natural regeneration. Among the carabid beetles which preferred tree stands on artificially prepared, ploughed soil, there were typical species of arable fields, e.g., H. rufipes, H. rufipalpis, or Poecilus lepidus. Skłodowski (2010), who studied the influence of various types of soil preparation in cleared forests on carabids, also demonstrated the relationship between more intensive soil preparation and the occurrence of $P$. lepidus, and a correlation between the presence of $C$. arvensis and reduced soil preparation. Among the spiders, the most numerous forest species $P$. lugubris and $P$. riparia clearly preferred natural tree stands without soil preparation. The artificially regenerated forest was dominated by $P$. pullata, which is an open habitat species. According to Pearce and Venier (2006), tree cutting does not eliminate all the fauna dwelling in a given site but leads to partial replacement of forest species with open habitat ones, which was also the case in this study. This finding provides evidence that human intrusion into the environment can contribute to the replacement of forest species by more tolerant open habitat species and generalists.

Large changes could also be observed in the trophic structure of carabid beetles. Some authors conclude that the predatory fauna is being replaced by a hemizoophagous one under unfavourable external conditions (Skłodowski 2014, Kosewska et al. 2014, Skalski et al. 2015, Magura et al. 2015). In the studied sites, the abundance of large predators, highly valuable in forest ecosystems, decreased in disturbed artificial and ploughed pine regeneration. Hemizoophages, which were the most numerous in all the experimental sites, are characteristic of man-made cultivations, although regeneration of a forest is a type of cultivation, in which some groups of animals such as carabid beetles and spiders are exposed to unstable conditions.

\section{Conclusions}

Natural pine regeneration can induce an increase in the diversity of some predatory arthropods, such as Araneae, in forests. Natural regeneration of pine stands without any preceding soil preparation, is the most beneficial variant of forest regeneration for carabid beetles and spiders. Preparation of soil by ploughing could be a factor which disturbs the stability of assemblages of ground beetles and spiders, leading to the replacement of forest species by open habitat species.

Acknowledgements: We are grateful to Dr S. Venn for valuable comments and improving the English. This work was supported by the grant: "Natural forest regeneration as a mean of decrease of deer browsing in Warmia and Mazury" funding from General Directorate of State Forests. We would like to thank Prof. J. Borkowski for allowing us to conduct research within the framework of the grant.

\section{References}

Aleksandrowicz, O.R. 2004. Biegaczowate (Carabidae). In: Bogdanowicz, W., E. Chudzińska, I. Pilipiuk, and E. Skibińska (Eds.). Fauna Polski - charakterystyka $i$ wykaz gatunków. Muzeum i Instytut Zoologii PAN. Warszawa. I: 28-42 [In Polish].

Aleksandrowicz-Trzcińska, M., S. Drozdowski, B. Brzeziecki, P. Rutkowska and B. Jabłońska. 2014. Effects of different methods of site preparation on natural regeneration of Pinus sylvestris in Eastern Poland. Dendrobiology 71: 73-81.

Anderson, M.J. 2001. A new method for non-parametric multivariate analysis of variance. Austral. Ecology 26:32-46.

Clarke, K.R. 1993. Non-parametric multivariate analyses of changes in community structure. Austral. J. Ecol. 18:117-143.

Debnár, Z., T. Magura, R. Horváth, D.D. Nagy, S. Mizser, A. Demkó, B. Tajthi and B. Tóthmérész. 2016. Group selection harvesting supports diversity of forest specjalist epigeic arthropods (Coleoptera: Carabidae; Arachnida: Araneae; Isopoda: Oniscidae). Period. Biol. 118:311-314.

Forests in Poland - report. 2016. Eds. Centrum Informacyjne Lasów Państwowych. Warszawa. pp. 56 [In Polish. www.lasy.gov.pl].

Hallikainen, V., M. Hyppönen, J. Hyvönen and J. Niemelä. 2007. Establishment and height development of harvested and naturally regenerated Scots pine near the timberline in North-East Finnish Lapland. Silva Fenn. 41:71-88.

Hammer O., D.A.T. Harperm, and P.D. Ryan. 2001. Paleontological Statistics software package for education and data analysis. Paleontol. Electron. 4:9.

Hänggi, A., E. Stöckli, and W. Nentwig. 1995. Habitats of Central European spiders. Miscellanea Faunistica Helvetiae 4:1-460.

Holland, J.M. and M.L. Luff. 2000. The effects of agricultural practices on Carabidae in temperate agroecosystems. Integr. Pest Manag. Rev. 5:109-129.

Huber, C., C. Schulze and M. Baumgarten. 2007. The effect of femeland small scale clear-cutting on ground dwelling spider communities in a Norway spruce forest in Southern Germany. Biodivers. Conserv. 16:3653-3680.

Hůrka, K. 1996. Carabidae of the Czech and Slovak Republics. Kabournek-Zlin.

Jelaska, L.Š, V. Dumbović and M. Kučinić. 2011. Carabid beetle diversity and mean individual biomass in beech forests of various ages. ZooKeys 100:393-405.

Junker, E.A., U.M. Ratschker and M. Roth. 2000. Impacts of silvicultural practice on the ground living-spider community (Arachnida: Araneae) of mixed mountain forests in the Chiemgau Alps (Germany). In: Gajdoś P. and S. Pekar (eds.), Proceedings of the 18th European Colloquium of Arachnology, Stara Leśna. Ekologia (Bratislava) 19(3):107-110.

Kaliszewski, A., E. Wysocka-Fijorek, M. Jabłoński and W. Młynarski. 2014. Update of the "National Forest Improvement Program". Documentation of the Forestry Research Institute [In Polish].

Kędzior, R., A. Szwalec, P. Mundała and T. Skalski. 2017. Ground beetle assemblages in recultivated and spontaneously regenerated forest ecosystems on post-industrial areas. Sylwan 161:512518 [In Polish]. 
Koivula, M.J. 2011. Useful model organisms, indicators, or both? Ground beetles (Coleoptera, Carabidae) reflecting environmental conditions. ZooKeys 100:287-317.

Koponen, S. 2005. Early succession of boreal spider community after forest fire. J. Arachnol. 33:230-235.

Kosewska, A., T. Skalski and M. Nietupski. 2014. Effect of conventional and non-inversion tillage systems on the abundance and some life history traits of carabid beetles (Coleoptera: Carabidae) in winter triticale fields. Eur. J. Entomol. 111 (5):669-676.

Kotze, J.D., P. Brandmayr, A. Casale, E. Dauffy-Richard, W. Dekoninck, M.J. Koivula, G.L. Lövei, D. Mossakowski, J. Noordijk, W. Paarmann, R. Pizzolotto, P. Saska, A. Schwerk, J. Serrano, J. Szyszko, A. Taboada, H. Turin, S. Venn, R. Vermeulen and T. Zetto. 2011. Forty years of carabid beetle research in Europe - from taxonomy, biology, ecology and population studies to bioindication, habitat assessment and conservation. ZooKeys 100:55-148.

Kromp, B. 1999. Carabid beetles in sustainable agriculture: a review of pest control efficacy, cultivation impact and enhancement. Agr. Ecosyst. Environ. 74:187-228.

Lindroth, C.H. 1985. The Carabidae (Coleoptera) of Fennoscandia and Denmark. Fauna Entomol. Scandinavica 15:1-225.

Lindroth, C.H. 1986. The Carabidae (Coleoptera) of Fennoscandia and Denmark. Fauna Entomol. Scandinavica 15:230-497.

Magura, T, D. Bogyó, S.Z. Mizser, D.D. Nagy and B. Tóthmérész. 2015. Recovery of ground-dwelling assemblages during reforestation with native oak depends on the mobility and feeding habits of the species. Forest Ecol. Manage. 339:117-126.

Maleque, M.A., K. Maeto and H.T. Ishii. 2009. Arthropods as bioindicators of sustainable forest management, with a focus on plantation forests. Appl. Entomol. Zool. 44 (1): 1-11.

Matuszkiewicz, J.M, A. Kowalska, A. Kozłowska, E. Roo-Zielińska and J. Solon. 2013. Differences in plant-species composition, richness and community structure in ancient and post-agricultural pine forests in central Poland. Forest Ecol. Manage. 310:567576.

Nagy, D.D., T. Magura, Z. Debnár, R. Horváth, B. Tóthmérész. 2015. Shift of rove beetle assemblages in reforestations: Does nativity matter? J. Insect Conserv. 19:1075-1087.

Nagy, D.D., T. Magura, S. Mizser, Z. Debnár and B. Tóthmérész. 2016. Recovery of surface-dwelling assemblages (Coleoptera: Carabidae, Staphylinidae) during clear-cut originated reforestation with native tree species. Period. Biol. 118:195-203.

Netwig, W., T. Blick, D. Gloor, A. Hänggi, and C. Kropf. 2017. Spiders of Europe. www.araneae.unibe.ch. Version 11. 2017, accessed on: 29.11.2017. doi: 10.24436/1.

Niemelä, J., D. Langor, J.R. Spence. 1993. Effects of clear-cut harvesting on boreal ground-beetle assemblages (Coleoptera: Carabidae) in Western Canada. Conserv. Biol. 7:551-561.

Oxbrough, A., S. Irwin, M. Wilson and J. O'Halloran. 2014. Mechanism and predictors of ecological change in managed forests: A selection of papers from the second international conference on biodiversity in forest ecosystems and landscapes. Forest Ecol. Manage. 321:1-4.

Oxbrough, A., T. Gittings, J. O’Halloran, P.S. Giller and G.F. Smith. 2005. Structural indicators of spider communities across the forest plantation cycle. Forest Ecol. Manage. 212:171-183.

Oxbrough, A., T. Gittings, J. O’Halloran, P.S. Giller and T.C. Kelly. 2006. The influence of open space on ground-dwelling spider assemblages within plantation forests. Forest Ecol. Manage. 237:404-417.
Paillet, Y., L. Bergès, J. Hjältén, P. Ódor, C. Avon, M. BernhardtRömermann, R. Bijlsma, L. De Bruyn, M. Fuhr, U. Grandin, R. Kanka, L. Lundin, S. Luque, T. Magura, S. Matesanz, I. Mészáros, M.-T. Sebastià, W. Schmidt, T. Standovár, B. Tóthmérész, A. Uotila, F. Valladares, K. Vellak and R. Virtanen. 2010. Biodiversity differences between managed and unmanaged forest: meta-analysis of species richness in Europe. Conserv. Biol. 24:101-112.

Pearce, J.L. and L.A. Venier. 2006. The use of beetles (Coleoptera: Carabidae) and spiders (Araneae) as bioindicators of sustainable forest management: a review. Ecol. Indic. 6:780-793.

Pedley, S.M. and P.M. Dolman. 2014. Multi-taxa trait and functional responses to physical disturbance. J. Anim. Ecol. 83:1542-1552.

Pigan, I. 2010. Natural regeneration of Scots pine (Pinus sylvestris L.) growing in moist habitats using different soil preparation metods. Sylwan 154:524-534 [In Polish].

Pohrl, G.R, D.W. Langor, J.R. Spence. 2007. Rove beetles and ground beetles (Coleoptera: Staphylinidae, Carabidae) as indicators of harvest and regeneration practices in western Canadian foothills forests. Biol. Conserv. 137:294-307.

Purvis, G., and A. Fadl. 2002. The influence of cropping rotations and soil cultivation practice on the population ecology of carabids (Coleoptera: Carabidae) in arable land. Pedobiologia 46:452-474.

Rainio, J. and J. Niemelä. 2003. Ground beetles (Coleoptera: Carabidae) as bioindicators. Biodivers. Conserv. 12:487-506.

Report of State of Europe's Forests. 2015. Ministerial Conference on the Protection of Forests in Europe. Forest Europe Liaison Unit Madrid. Spain.

Samu, F., F. Kádár, G. Ónodi, M. Kertész, A. Szirányi, É. Szita, K. Fetykó, D. Neidert, E. Botos and V. Altbäcker. 2010. Differential ecological responses of two generalist arthropod groups, spiders and carabid beetles (Araneae, Carabidae), to the effects of wildfire. Community Ecol. 11:129-139.

Schuldt, A., N. Fahrenholz, M. Brauns, S. Migge-Kleian and M. Schaefer. 2008. Communities of ground-living spiders in deciduous forests: Does tree species diversity matter? Biodivers. Conserv. 17:1267-1284.

Schwerk, A. and J. Szyszko. 2007. Successional patterns of carabid fauna (Coleoptera: Carabidae) in planted and natural regenerated pine forests growing on old arable land. Baltic J. Coleopterol. 7:9-16.

Schwerk, A. and J. Szyszko. 2011. Model of succession in degraded areas based on carabid beetles (Coleoptera, Carabidae). In: Kotze D.J., T. Assmann, J. Noordijk, H. Turin and R. Vermeulen (Eds.). Carabid Beetles as Bioindicators: Biogeographical, Ecological and Environmental Studies. ZooKeys 100:319-332.

Sharova, I.H. 1974. Zhiznennye formy imago zhuzhelits (Coleoptera, Carabidae). Zool. Zhurn. 53 (5):692-709 [In Russian].

Sipos, J., J. Hodecek, T. Kuras and A. Dolny. 2017. Principal determinants of species and functional diversity of carabid beetle assemblages during succession at post-industrial sites. Bull. Entomol. Res. 107 (4):466-477.

Skalski, T., R. Kędzior, D. Kolbe and S. Knutelski. 2015. Ground beetles as indicators of heavy metal pollution. Sylwan 159:905911 [In Polish].

Skłodowski, J.J. 2010. Carabid communities as zooindicators of soil scarification techniques applied in clear-cutted forest stands and the further used management practices. Sylwan 154:625-638 [In Polish].

Skłodowski, J.J. 2014. Effects of top-soil preparation and broadleaved tree mixture on carabid beetles in afforested fallow plots. Restor. Ecol. 22:13-21. 
Skłodowski, J.J. 2016. Manual soil preparation and piles of branches can support ground beetles (Coleoptera, carabidae) better than four different mechanical soil treatments in a clear-cut area of a closed-canopy pine forest in northern Poland. Scand. J. Forest Res. 32 (2):123-133.

Szramka, H. 2005. Economic aspects of different ways of renovation of forest. Sylwan 11:59-65 [In Polish].

Taboada, A., R. Tárrega, L. Calvo, E. Marcos, J.A. Marcos and J. M. Salgado. 2010. Plant and carabid beetle species diversity in relation to forest type and structural heterogeneity. Eur. J. For. Res. 129:31-45.

Tamutis, V. and J.J. Skłodowski. 2016. Coleoptera assemblages of pine forests depends on the distance to the source of nitrogen pollution. Community Ecol. 17:225-236.

World Spider Catalog (2017). Natural History Museum Bern, online at http://wsc.nmbe.ch, version 18.5, accessed on 29.11.2017. doi: $10.24436 / 2$.

Received November 30, 2017

Revised April 20, May 20, 2018

Accepted May 30, 2018

\section{Appendix}

Table A1. SIMPER analysis for the carabid beetles contributing more than $1 \%$ to the dissimilarity between treatments: Natural regeneration $(\mathrm{N})$ - Natural regeneration with ploughed soil $(\mathrm{N}+\mathrm{P})$ -Artificial regeneration (A)

Table A2. SIMPER analysis for the Araneae contributing more than $1 \%$ to the dissimilarity between treatments: Natural regeneration $(\mathrm{N})$ - Natural regeneration with ploughed soil $(\mathrm{N}+\mathrm{P})$ Artificial regeneration (A)

The file may be dowloaded from www.akademiai.com. 